instilling in them the courage to criticize even the masters in the field.

As a curator he "practiced what he preached." Armed only with his magnifying glass-which he invariably wore in the pocket of one of his colorful vests - he set off week after week, here or abroad on the hunt, or to borrow a phrase-"on the chase and capture." He loved going around to dealers and auction houses and surprising his colleagues with his latest finds. He was almost like a child at Christmas when showing off his latest treasure. It was at times like these when his general reserve gave way to boyish enthusiasm: he could not stifle a wide grin or the huge twinkle in his eye. He was very proud of himself. And rightly so. And this excitement, needless to say, was contagious.

Richard Ettinghausen's passing is the end of an era in the field of Islamic art and, as the Persians would say, "his place is very empty." But let us not mourn his death; let us celebrate his life because, through his writings, his students, and the collections he formed, he will live forever.

Marilyn Jenkins

Metropolitan Museum of Art, N.Y.

\title{
VERONIKA GERVERS
}

[1939 - 1979]

The number of Islamic art historians and archeologists is still small compared with scholars in other fields of Islamic studies-and every contributor counts. The death of Veronika Gervers on July 21, 1979, after a sudden illness, leaves us all the poorer, in light of the promise which her brief but productive career held forth and the unique position which she had established for herself in this field.

She will best be remembered for the enthusiasm and scholarship that she brought to an otherwise neglected area-Islamic textiles-eschewed by most art historians because of the rare technical knowledge it demands. Through warm, personal exchanges and through her publications, she heightened our awareness of the importance of textiles to an understanding of Islamic art and social history.

Veronika was born in Hajdúnánás, Hungary, in 1939. She received her doctorate at the University of Budapest in Medieval Art History in 1965, and served as field director of a number of archeological excavations at Sarospatak. She was Associate Curator at the Rakbczi Museum, Sarospatak, and Later, lecturer at the Institute of Historical Monuments of Budapest.

Veronika came to Canada and joined the Royal Ontario Museum's Textile Department in 1968. She was Associate Curator, responsible for the research and display of Oriental and East European textiles, costumes, carpets and jewelry. She also held a cross-appointment to the University of Toronto. While continuing her studies of East European textiles, Veronika soon developed an interest in the Near Eastern collections of the Museum. This led to extended field studies in rural Turkey and Iran, documenting local felt-making traditions in particular. One of her major interests was the Eurasian origin of certain European costumes, such as the Hungarian shepherd's mantle (The 
Hungarian Szur: An Archaic Mantle of Eurasian Origin; ROM 1973). She was instrumental in obtaining for the Royal Ontario Museum the unique Michel Abemoyor Collection of early Christian and Islamic textiles, numbering almost 1,200 items.

Veronika published articles in both English and Hungarian, and was editor of Studies in Textile History in Memory of Harold Burnhom (ROM 1977). She represented Canada at the Centre International d'Etude des Textiles Anciens at Lyon, France; served as editorial advisor for Textile History; and was corresponding editor for Canadian-American Review of Hungarian Studies. With children's author, Elizabeth Cleaver, she co-authored The Miraculous Hind: A Hungarian Legend, a book acclaimed for its authentic costume illustrations.

Veronika's untimely death is a tragic loss to the field and a great personal loss to her close friends. The Royal Ontario Museum has established a research fund to bring to completion some of the many projects in which she had been engaged.

Lisa Golombek

Royal Ontario Museum 